\title{
Biomagnifications of mercury and methylmercury in tuna and mackerel
}

\begin{abstract}
Seawater may be contaminated by harmful substances, including toxic elements released by human activities. The present study evaluates the total mercury and methylmercury concentrations and their correlations to fish body size in longtail tuna and short-bodied mackerel from Chendring, Kuantan, at east coast and Kuala Perlis at west costs of Peninsular Malaysia during May to November 2007. Total mercury and methylmercury in muscle tissue of 69 samples of longtail tuna and short-bodied mackerel, ranged from 0.180 to $1.460 \mu \mathrm{g} / \mathrm{g}$ and $0.0 .169-0.973 \mu \mathrm{g} / \mathrm{g}$ and $0.251-1.470 \mu \mathrm{g} / \mathrm{g}$ and $0.202-1.352$, whereas the methylmercury to total mercury ratio ranged from $70 \%$ to $83 \%$, respectively. Samples of both species from the east coast showed higher levels of mercury compared to those from west coast. In all of the locations, significant positive correlations were found between fish body weight and mercury content $(\mathrm{R}(2)>0.470)$. The estimated weekly intake of total mercury and methylmercury from the consumption $66.33 \mathrm{~g} /$ week of short-bodied mackerel and $18.34 \mathrm{~g} /$ week of longtail tuna (based on local dietry survey) was found to be lower than the maximum limit of 5 and $1.5 \mu \mathrm{g} / \mathrm{kg}$ bodyweight established by FAO/WHO and codex, respectively.
\end{abstract}

Keyword: Mercury; Methylmercury; Biomagnification; Tuna; Mackerel 